\title{
Coronary stent deployment to the iliac artery - a complication with a successful treatment
}

Przemieszczenie stentu wieńcowego do tętnicy biodrowej - powikłanie ze szczęśliwym zakończeniem

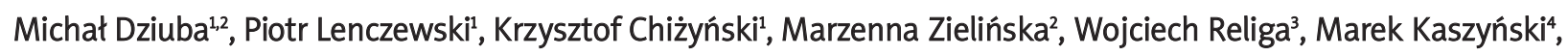 \\ Ludomir Stefańczyk ${ }^{5}$, Michał Kidawa ${ }^{1}$
}

${ }^{1}$ Catheterization Laboratory, Invasive Cardiology Unit, Chair of Cardiology and Cardiac Surgery, Medical University of Lodz, Poland

Intensive Cardiac Therapy Clinic, Chair of Cardiology and Cardiac Surgery, Medical University of Lodz, Poland

${ }^{3}$ Angiography and Haemodynamics Laboratory, ZOZ MSWiA, Lodz, Poland

${ }^{4}$ Department of Vascular Surgery, ZOZ MSWiA, Lodz, Poland

51st Department of Radiology and Diagnostic Imaging, Medical University of Lodz, Poland

Postep Kardiol Inter 2012; 8, 2 (28): 146-152

DOI: $10.5114 /$ pwki.2012.29656

\begin{abstract}
We report a description of angioplasty $(\mathrm{PCl})$ of the right coronary artery in a 68-year-old man with stable coronary artery disease and peripheral vascular atherosclerosis. The treatment was complicated by stent dislocation into the substantially narrowed iliac artery without accompanying signs of acute limb ischaemia. Vascular stent implantation was performed in the place of the stenosis of the left external iliac artery with simultaneous crushing of the non-expanded coronary stent into the vessel wall.
\end{abstract}

Key words: percutaneous coronary intervention, coronary stent loss

\section{Streszczenie}

Prezentujemy przypadek angioplastyki prawej tętnicy wieńcowej u 68-letniego mężczyzny z chorobą wieńcową oraz ze wspótistniejącą miażdżycą zarostową kończyn dolnych. Zabieg był powikłany przemieszczeniem stentu do istotnie zwężonej tętnicy biodrowej bez objawów ostrego niedokrwienia kończyny dolnej. Zastosowano skutecznie implantację kolejnego stentu naczyniowego w miejscu istotnej stenozy w naczyniu obwodowym z jednoczesnym przykryciem nierozprężonego stentu wieńcowego.

Słowa kluczowe: angioplastyka wieńcowa, przemieszczenie stentu wieńcowego

\section{Introduction}

Percutaneous coronary intervention (PCI) together with well-managed pharmacotherapy is currently the method of choice in the treatment of symptomatic coronary artery disease (CAD). Introduction of stents significantly improved both early and late results of $\mathrm{PCl}$. Continuous technological progress regarding produced stents, catheters and guidewires has resulted in higher efficacy of invasive CAD treatment. On the other hand, patients qualified for $\mathrm{PCl}$ are now burdened with more adverse risk factors and are characterized by more complex morphology of athero- sclerotic plaques. Even a few years ago these patients were more frequently referred for cardiac surgery. Any physician performing percutaneous coronary interventions should possess both theoretical knowledge and practical skills that will offset the risk of harm to the patient in case of complications. Progress towards improvement of equipment used in interventional cardiology has caused a much lower incidence of some complications. These include uncontrolled stent slipping off the balloon into the coronary artery. The complication continues to occur despite the widespread introduction of prefabricated balloonmounted stents, which eliminated some complications 
dependent on the operator, who not so long ago had to manually mount the stent on the balloon catheter.

\section{Case report}

The theme of our report is a case of coronary angioplasty in a 68-year-old man. The patient was admitted electively to the Department of Cardiology of the Chair of Cardiology and Cardiac Surgery of the Medical University of Lodz in April 2011 because of the symptoms of angina occurring for about a year, recently in class II/III of the Canadian Cardiovascular Society (CCS). His medical history included a 10-year history of hypertension, two previous strokes currently without significant paralysis (Dec 2006 and Jan 2011), previous endarterectomy of the right internal carotid artery (Jul 2007) and signs of a chronic lower limb ischemia with claudication distance of 500 m. Physical examination on admission to the ward revealed no pulse in peripheral arteries of the left foot and a weak pulse in homologous arteries of the right foot. Electrocardiogram showed sinus rhythm (72 beats per minute), axis deviation to the left and no signs of acute or chronic myocardial ischaemia, arrhythmias or conduction abnormalities. Echocardiography demonstrated symmetric left ventricular contractility with preserved left ventricular ejection fraction $(\mathrm{EF}=61 \%)$ and good right ventricular function (TAM $=24 \mathrm{~mm}$ ). There were no abnormalities in the laboratory findings (creatinine $79 \mu \mathrm{mol} / \mathrm{l}$, glucose $4.6 \mathrm{mmol} / \mathrm{l}$, total cholesterol $3.6 \mathrm{mmol} / \mathrm{l})$. The patient was treated according to cardiological guidelines with the use of aspirin, metoprolol, ramipril, atorvastatin, nitrendipine and pentoxifylline, with good control of hypertension. Because of the typical chest pain and clinical data confirming multilevel athero- sclerosis, the patient was qualified for invasive diagnostics of CAD. Selective right (RCA) and left (LCA) coronary angiography were performed via the right radial artery (Figure 1). There were no significant lesions in the LCA and multilevel atherosclerotic lesions with intramural calcifications in the RCA including 70\% narrowing in the $2^{\text {nd }}$ segment followed by $95 \%$ narrowing located over the inferior wall and $70 \%$ narrowing before the crux cordis. Atherosclerotic changes in the RCA were considered to be the cause of symptoms reported by the patient and the decision to perform percutaneous intervention was taken.

After administration of unfractionated heparin, sequential predilation of the RCA (in segments 2, 2/3 and 3) using an Avion balloon was performed (Figure 2).

This was followed by an attempt to deliver the Liberte $2.75 / 20 \mathrm{~mm}$ stent to the distal part of the RCA. It was impossible to pass the stent below the $2^{\text {nd }}$ segment of the artery (Figure 3). The reason for difficulties in continuation of the procedure was the complex morphology of atherosclerotic plaques including their calcifications. Because of the lack of sufficient support and bail out of the guiding catheter (JR4) it was changed for an AR1 catheter. This enabled the execution of three additional inflations (in segments 2, 2/3, 3) using a larger balloon catheter (Avion 3.0/20 mm, $12 \mathrm{~atm}$ ).

Despite earlier adaptation of the vessel the passage of a stent through the $2^{\text {nd }}$ segment was difficult again. Finally it was possible to perform a successful implantation of the Liberte $2.75 / 20 \mathrm{~mm}$ stent $(16 \mathrm{~atm})$ in the $2^{\text {nd }} / 3^{\text {rd }}$ segment (Figure 4).

Subsequently a decision was taken to implant another stent in the descending part of the RCA. During an attempt to pass the Liberte $3.0 / 28 \mathrm{~mm}$ stent through
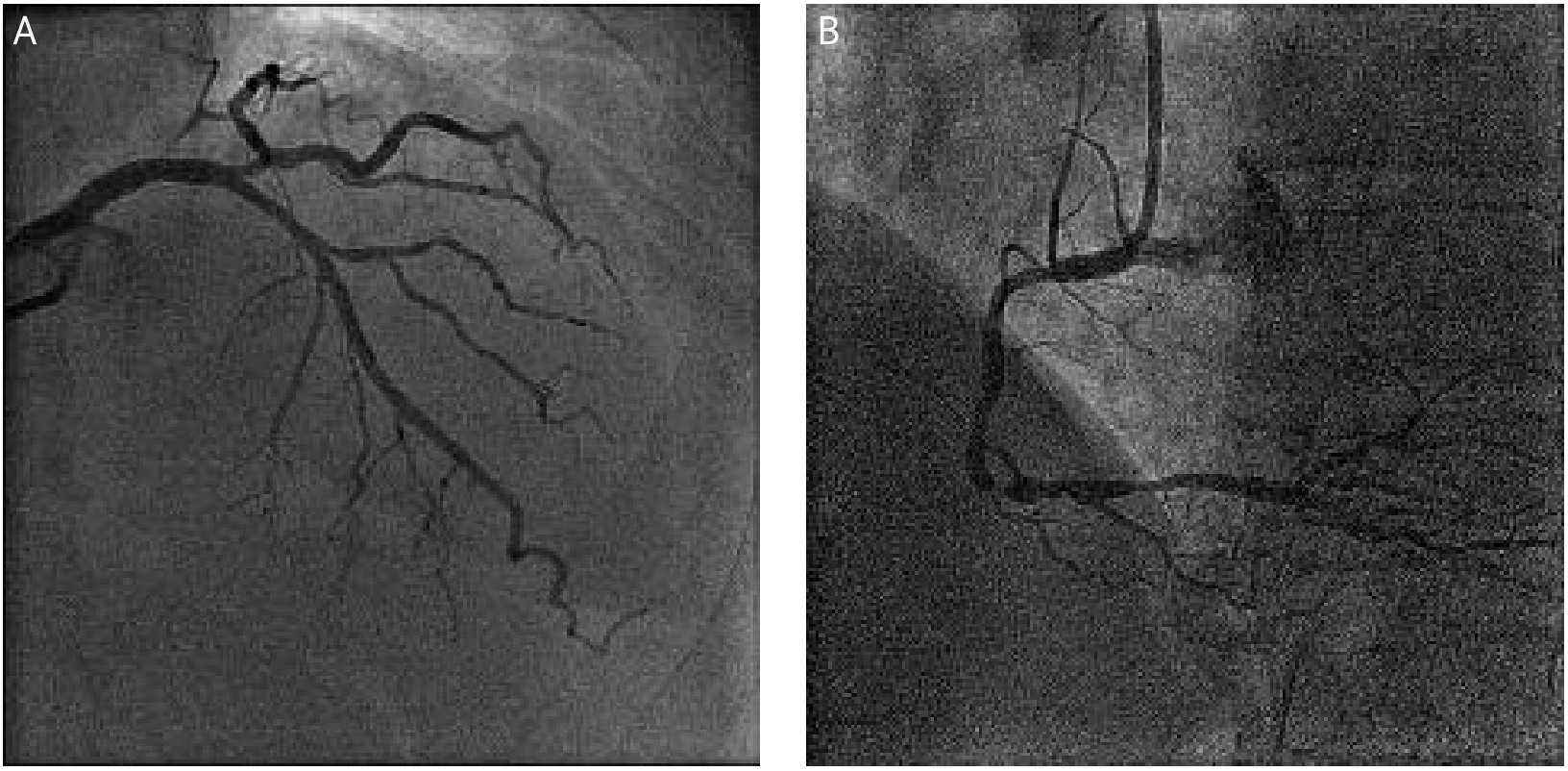

Fig. 1. Angiography of the left (A) and right (B) coronary artery

Ryc. 1. Angiografia lewej (A) i prawej (B) tętnicy wieńcowej 

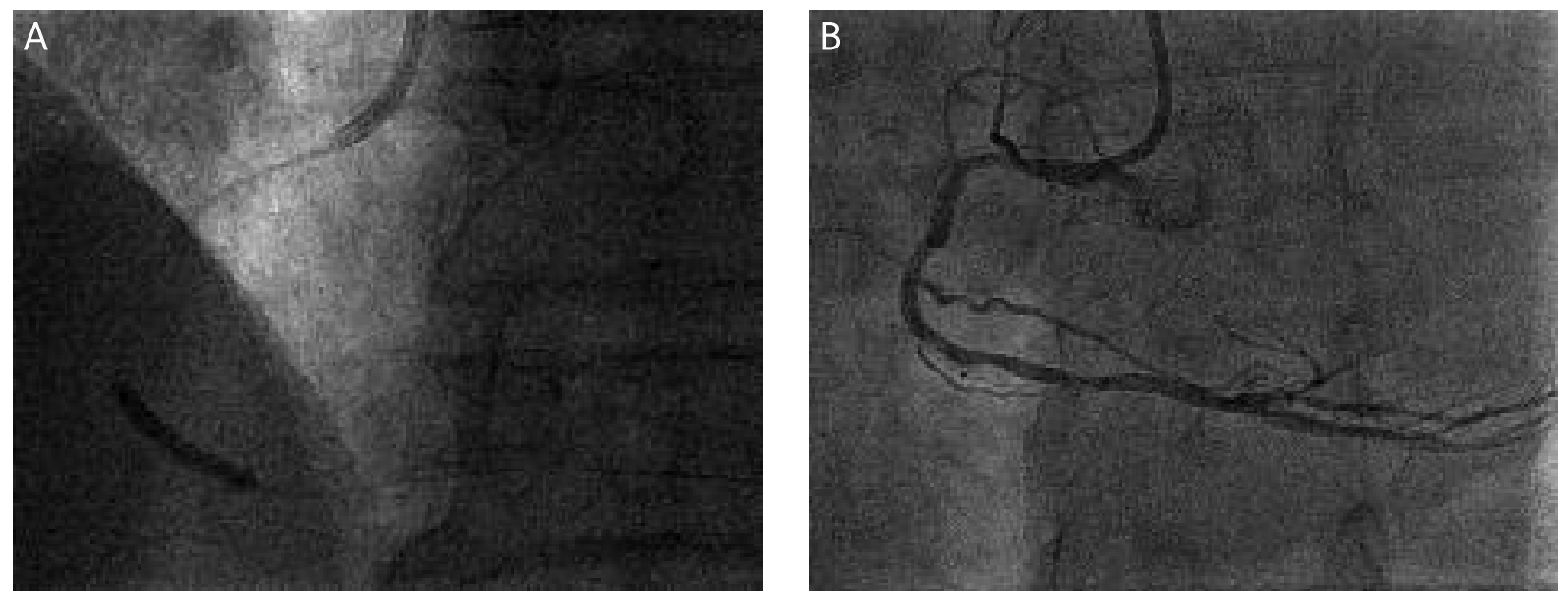

Fig. 2. Balloon angioplasty (Avion $2.5 / 20 \mathrm{~mm}$ ) of the RCA (A) and status after balloon angioplasty with the Avion balloon 2.5/20 mm (B)

Ryc. 2. Angioplastyka balonowa (Avion 2,5/20 mm) PTW (A) oraz stan po angioplastyce balonem Avion 2,5/20 mm (B)
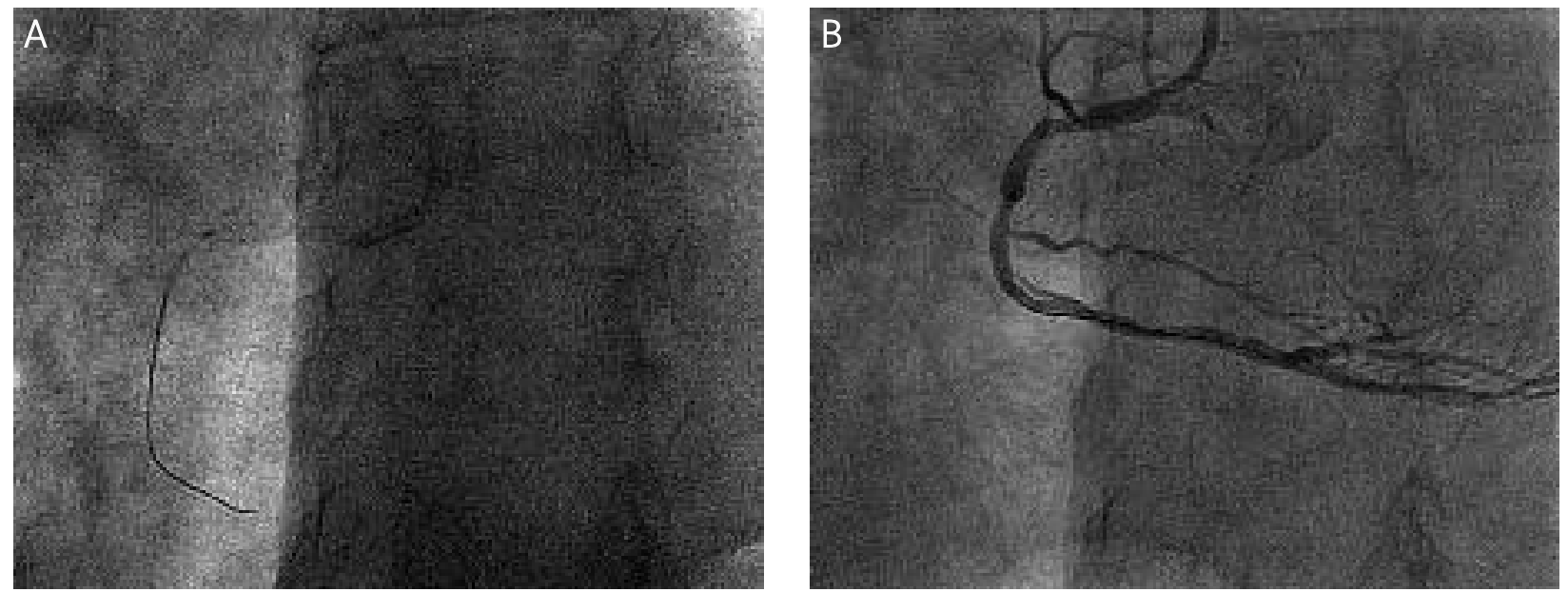

Fig. 3. Unsuccessful attempt to pass the Liberte stent $(2.75 / 20 \mathrm{~mm})$ through the $2^{\text {nd }}$ segment $(\mathrm{A})$; status after angioplasty with a 3.0/20 mm balloon (B)

Ryc. 3. Nieudana próba przejścia stentem Liberte 2,75/20 mm przez segment 2. (A) oraz stan po angioplastyce balonem 3,0/20 mm (B)
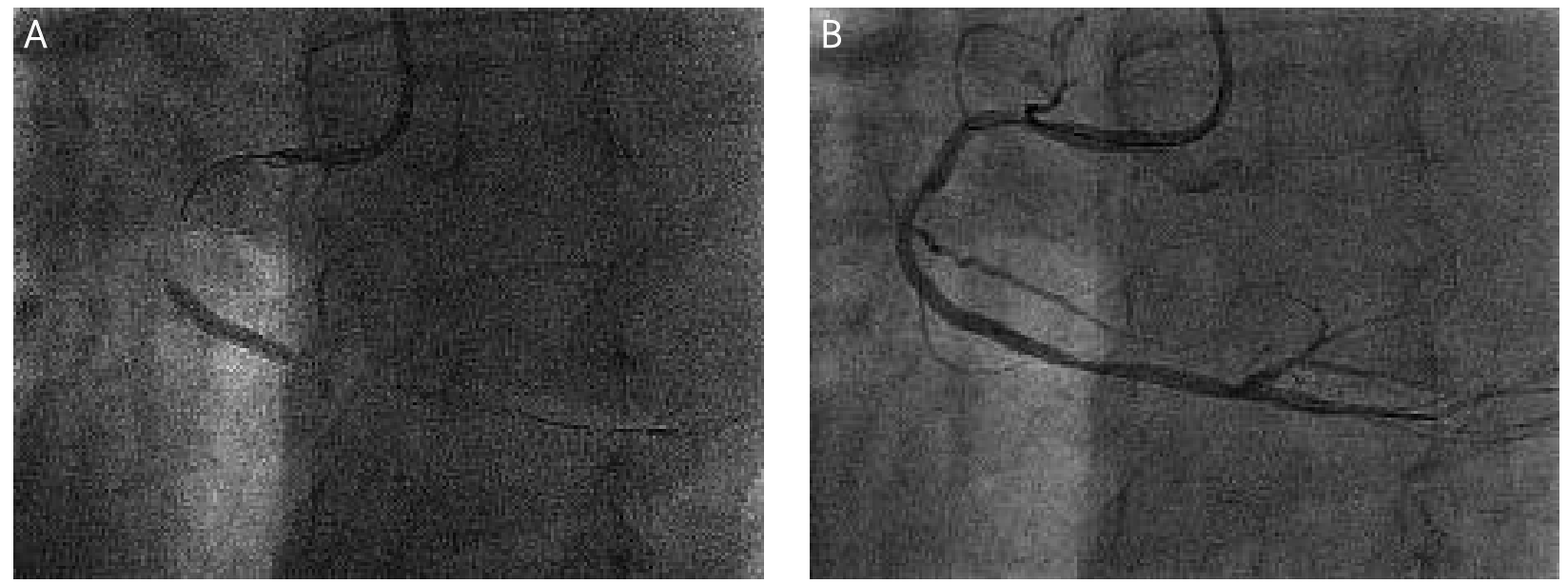

Fig. 4. Implantation of the Liberte $2.75 / 20 \mathrm{~mm}$ stent $(\mathrm{A})$ and post-PCl effect (B)

Ryc. 4. Implantacja stentu Liberte $2,75 / 20 \mathrm{~mm}(\boldsymbol{A})$ oraz stan po angioplastyce (B) 

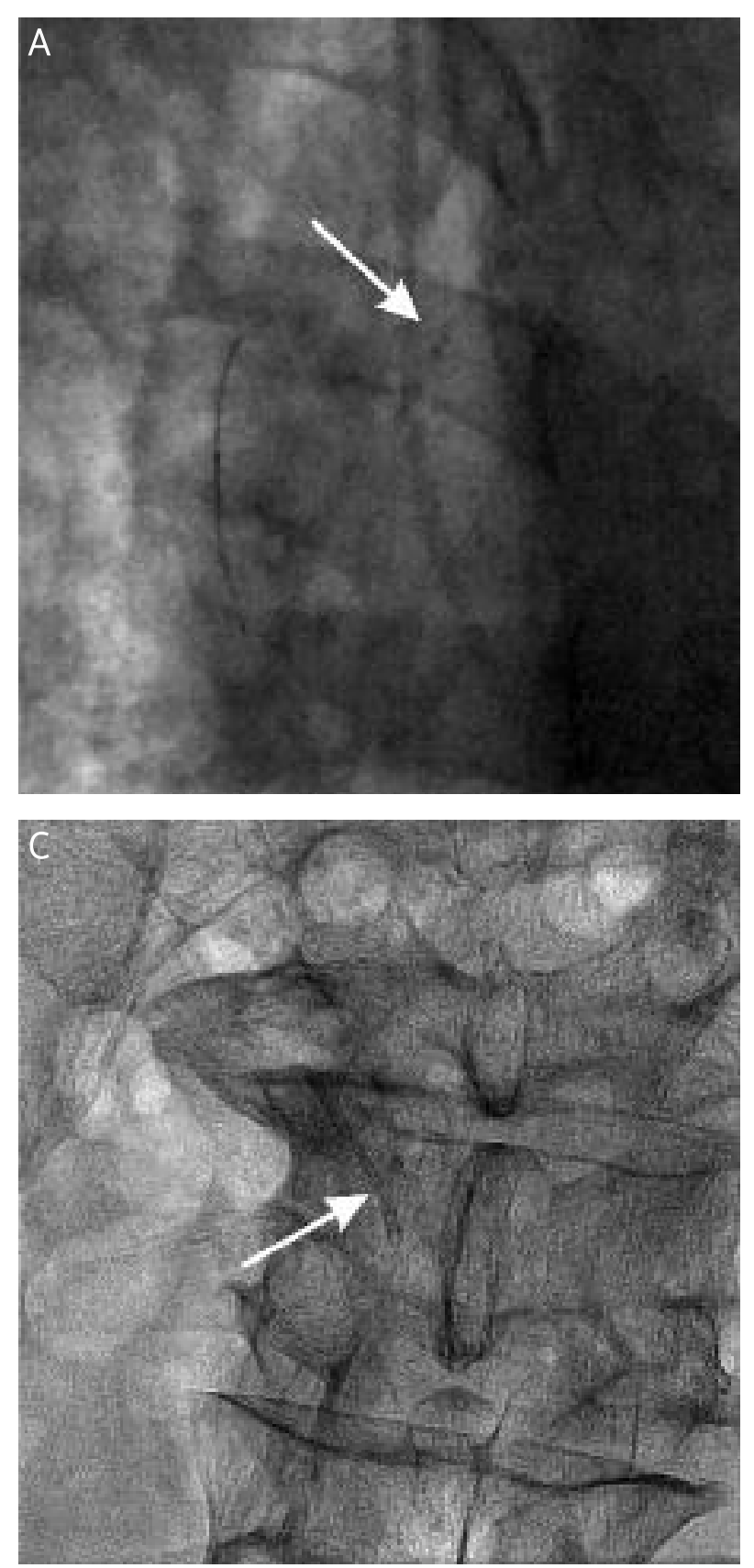

the $2^{\text {nd }}$ segment the stent slipped off the balloon catheter and the whole system was bailed out to the ascending aorta. The stent remained at the tip of the guidewire. During an attempt to evacuate the stent it slipped off the guidewire and was dislocated to the peripheral circulation. The dislocated stent was then found at the level of the left iliac arteries (Figure 5).

Because of the stable clinical condition of the patient and no symptoms of acute lower limb ischaemia, attempts to evacuate the stent using other methods were postponed. A loading dose of clopidogrel was administered. In the following days the patient's condition was good, he did not complain of angina and there were no ST-T segment changes recorded on the ECG. Physical examination did not reveal

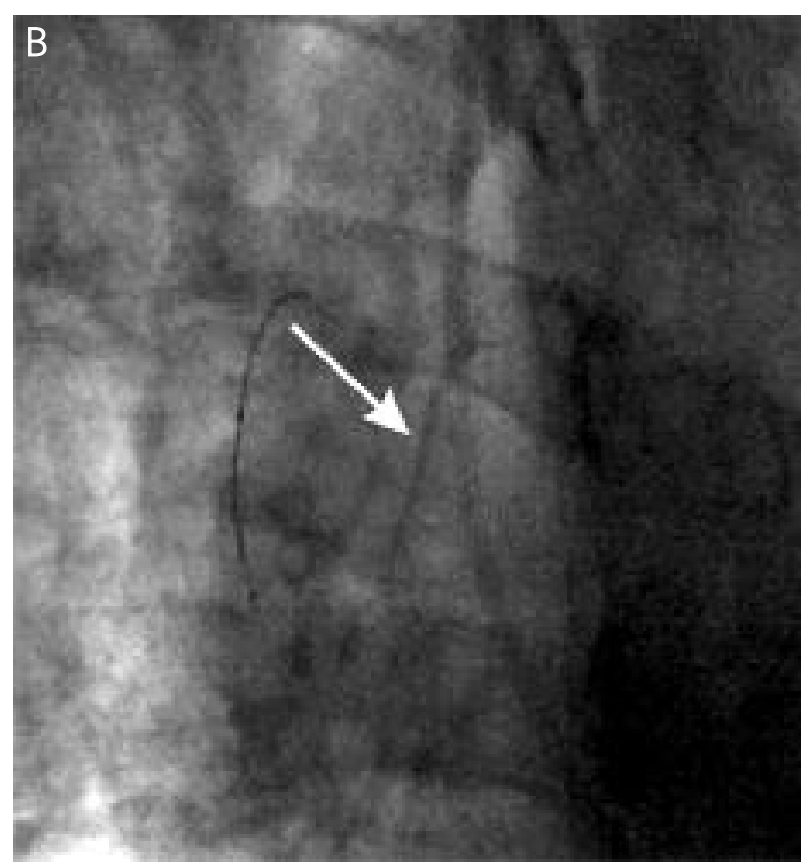

Fig. 5. The moment of stent dislocation to the peripheral circulation and the visible stent in the left iliac arteries (fluoroscopy: A, B, C)

Ryc. 5. Moment przemieszczenia stentu do krążenia systemowego oraz widoczny stent $w$ rzucie naczyń biodrowych po stronie lewej (fluoroskopia: $A, B, C)$

any symptoms of acute lower limb ischaemia. There was a mild increase of troponin T concentration after the procedure (TnT hs: $1^{\text {st }}$ day $-0.103 \mathrm{ng} / \mathrm{ml} ; 7^{\text {th }}$ day $-0.051 \mathrm{ng} / \mathrm{ml}$; reference values up to $0.014 \mathrm{ng} / \mathrm{ml}$ ) without an increase of creatine kinase-MB.

Because of the history of chronic lower limb ischaemia the patient was referred for computed tomography (CT) of the lower limbs in order to assess the possibility of stent evacuation and to choose the method of revascularization. The CT examination showed significant stenosis in the proximal part of the left external iliac artery and occlusion of the left femoral superficial artery with well-developed collateral circulation. The dislocated stent was visualized in the left common iliac artery (Figure 6). 

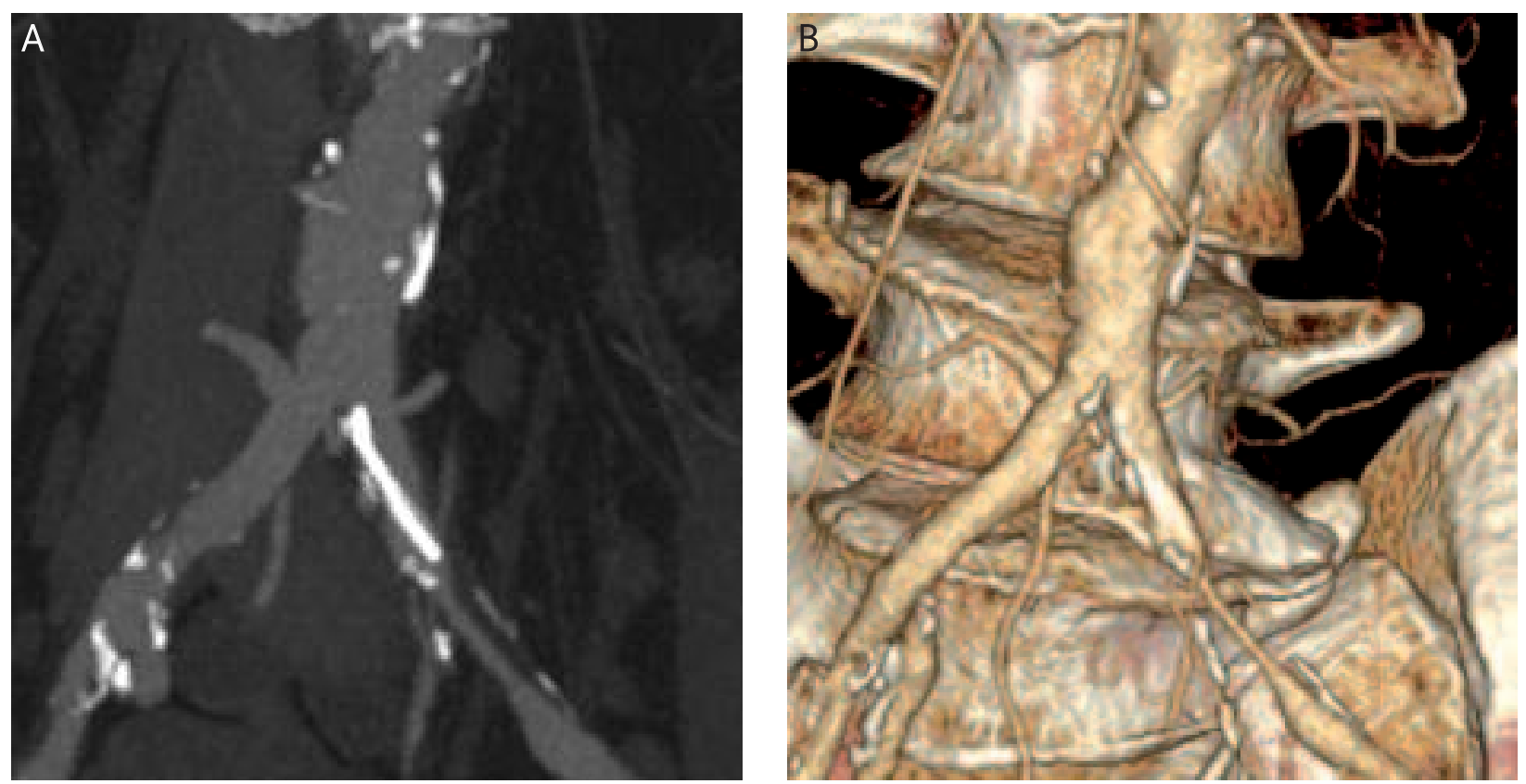

Fig. 6. The stent at the level of left iliac arteries located proximally to the significant stenosis (angio-CT) (A, B) Ryc. 6. Widoczny stent $w$ rzucie naczyń biodrowych po stronie lewej, proksymalnie od istotnego zwężenia (angio-CT) $(A, B)$

After consultation with the vascular surgeon the patient was qualified for intravascular treatment and underwent angiography of the left iliac artery in the Angiography and Haemodynamics Laboratory of the MSWiA Hospital in Lodz. Significant stenosis of the left external iliac artery was confirmed (Figure 7). The patient was qualified for angioplasty with an attempt to crush the stent into the iliac artery wall. The stenosis was treated with implantation of the Assurant Kobalt 8/40 mm stent (12 atm) which successfully covered the intracoronary stent. Dissection in the proximal part of the stent required prolonged inflation with the balloon catheter $8 / 40 \mathrm{~mm}$ (14 atm) (Figure 7). After the procedure the patient's condition was good and no complications were observed. The ankle-brachial index (ABI) remained unchanged, which was probably caused by advanced atherosclerosis present in the distal segments of the arteries supplying the left lower limb (ABI before 0.5; after 0.5).

\section{Discussion}

We have presented a case of complicated $\mathrm{PCl}$ of the RCA. During positioning the stent slipped off the balloon and migrated to the peripheral arteries. According to published registries the frequency of stent slippage during $\mathrm{PCl}$ may range between $0.32 \%$ and $8.3 \%$ [1]. Certainly, the main cause of this complication in previous decades was the use of stents manually crimped on the intracoronary balloons. In the study of Eggebrecht et al. the frequency of stent slippage was significantly lower for stents premounted on the balloons in comparison to manually crimped stents $(0.27 \%$ vs. $1.04 \% ; p<0.01)$ [2]. The causes of uncontrolled non-dilated stent slippage off the balloon catheter are multiform. They include complex morphology of atherosclerotic plaque at the site of stenosis, advanced intramural calcification, tortuous course of the vessel, choice of direct stent implantation without previous pre-dilation, type of stent, lower diameter of the guiding catheters and attempts to pass the stent through a segment of the vessel which was previously treated with stent implantation [2]. In the opinion of the authors in the present case the decisive factors were vessel tortuosity and the presence of calcifications. Consequences of coronary stent slippage depend mainly on whether the stent remains in the coronary arteries or becomes dislocated to the peripheral circulation. Asymptomatic clinical course after this type of complication is also possible. Embolization to the peripheral arteries may cause symptoms of ischemia such as claudication, infarction of parenchymal organ or stroke. If the stent is left in the coronary artery it may cause myocardial infarction, the extent of which will depend largely on the extent of the area supplied by the artery with the dislocated stent. A slipped stent may occasionally result in the patient's death [1, 2]. In the study of Bolte et al. there was a higher frequency of mortality in the group of patients with a failed attempt to evacuate a stent left in the coronary artery in comparison to patients in whom the evacuation of the slipped stent was successful (17.0\% vs. $0.9 \%$; $p<0.001$ ) [3]. The risk factor for stent slippage in the present case might have been advanced atherosclerosis. Stenosis in the iliac artery stopped the flowing stent and localized it in a good position for percutaneous interven- 

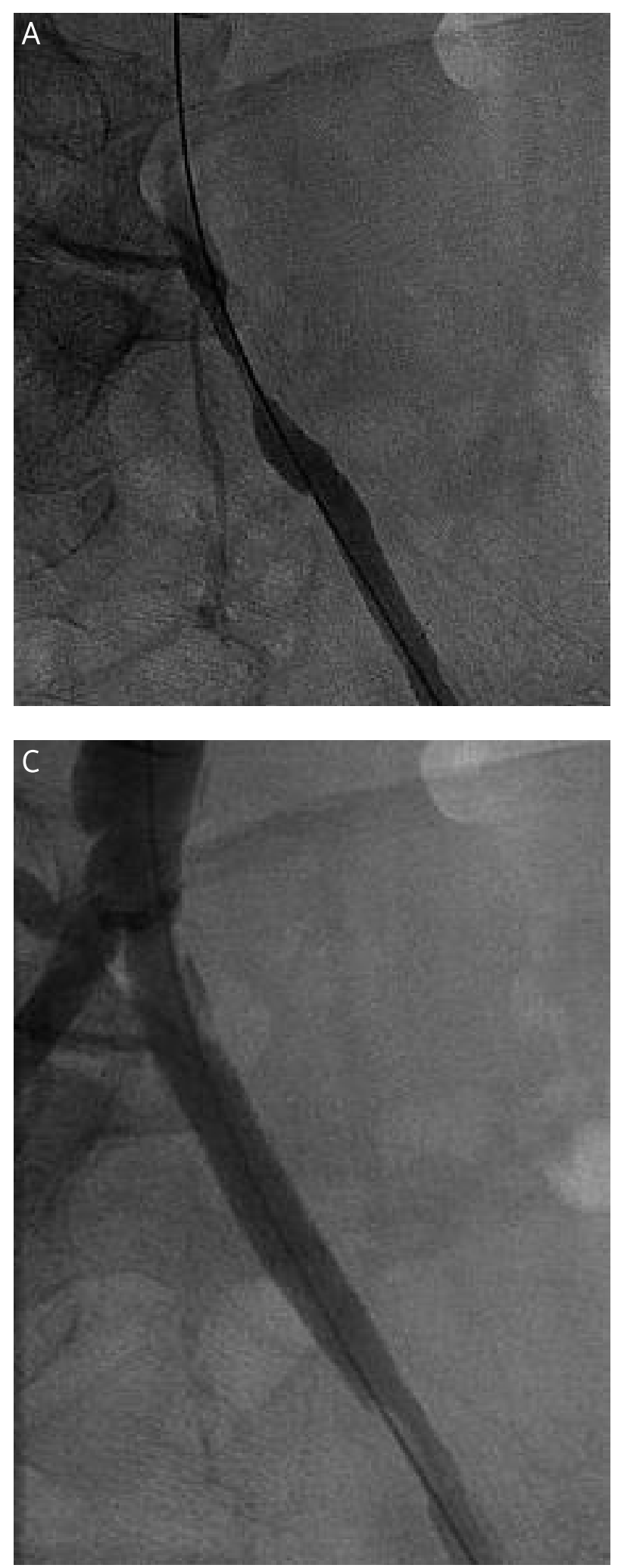

tions leading to its evacuation or crushing into the vessel wall in case of a decision to dilate the iliac artery.

There are no guidelines on the management of slipped stents. Retrieval of a lost stent is not always successful. Analysis of six registries of patients in whom a stent was

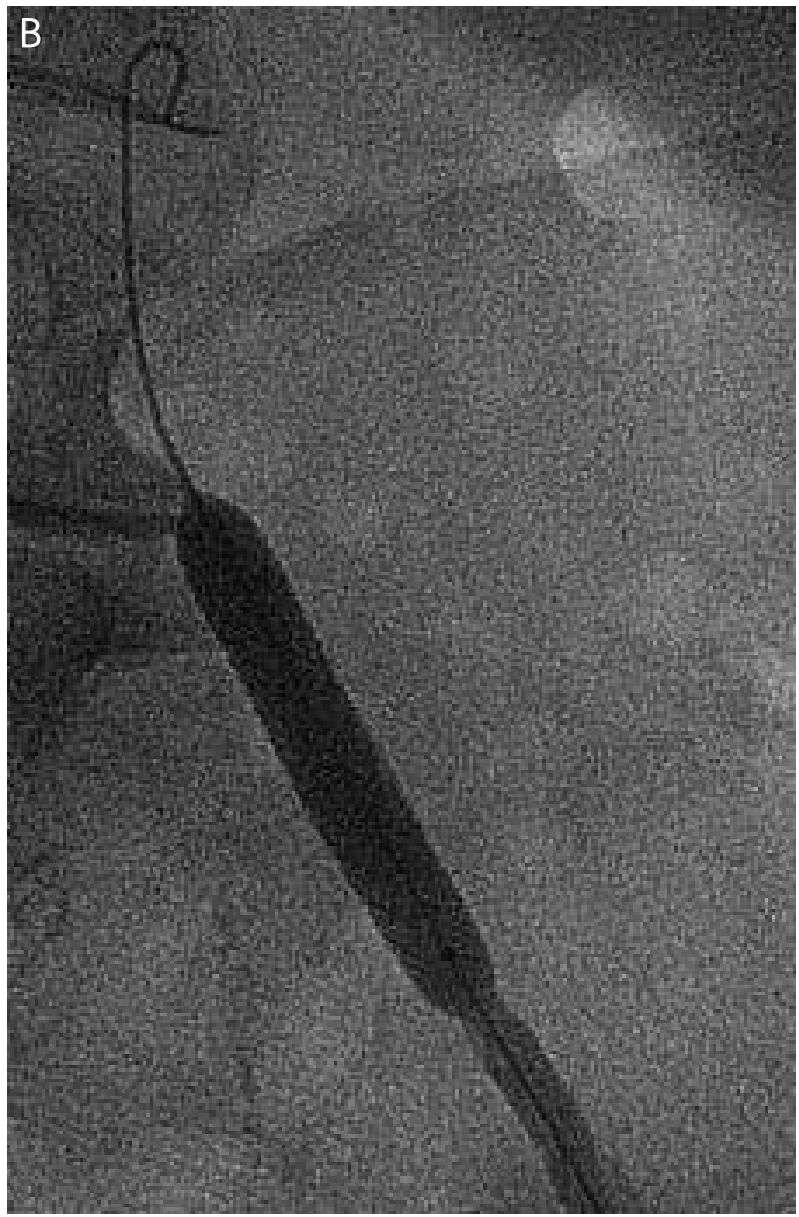

Fig. 7. Angiography of the left external iliac artery with visible stenosis (A) and implantation of the Assurant Kobalt stent $8 / 40 \mathrm{~mm}$ (B) with the final effect $(\mathrm{C})$

Ryc. 7. Angiografia tętnicy biodrowej zewnętrznej lewej z widocznym zwężeniem (A) oraz implantacja stentu Assurant Kobalt $8 / 40 \mathrm{~mm}$ (B), efekt ostateczny $(\boldsymbol{C})$

dislocated during $\mathrm{PCl}$ showed that its evacuation was possible in 45 to $100 \%$ of cases [1]. The methods of treatment of this kind of complication depend mainly on whether the unexpanded stent is left in the coronary artery or in the peripheral artery. These include: 
- When the aim is to remove the stent:

- The use of a small diameter, low-profile balloon. The condition is that the stent must remain on the guidewire. This approach is attempted with the balloon passing distally to the stent. The balloon is then expanded under low pressure and removed together with the stent into the guiding catheter. This method was ineffective in the present case, because of the extreme position of the stent at the tip of the guidewire.

- Technique using two guidewires. The second guidewire should be placed parallel to the first one but outside of the stent and then tangled with the tip of the second guidewire. If the tangled guidewires stabilize the whole system there is a chance for successful removal of the stent into the catheter.

- Evacuation of the stent using commercial intravascular microloops (such as Amplatz goosenseck, Microvena, MN).

- In case of stent localization in the lumen of a large peripheral vessel it may be possible to use systems dedicated for evacuation of other objects. These include forceps used for bile duct surgery, Cook systems used to remove electrodes, baskets used to remove renal or gall stones and forceps used for endomyocardial biopsy.

- Surgical removal.

- When the aim is to leave the stent:

- Crossing with the balloon through the lumen of an unexpanded stent and its expansion in a different, preferentially distal segment of the artery (if attempts to position a stent in a primarily used location are unsuccessful).

- The use of a different stent, which should be implanted in the location of the slipped stent with an attempt to crush its struts into the vessel wall. This method may be used in case of stent dislocation into the coronary artery and peripheral artery. The procedure should not be performed in the left main stem or in the proximal part of the left anterior descending artery. Detailed long-term results of this technique are unknown, which is important especially for interventions on the coronary arteries.

- Urgent direct revascularization in case of stent dislocation in the coronary artery.

- No further actions and observation in case of stent dislocation to the peripheries of the systemic circulation with an asymptomatic course.

In the present case, the patient was successfully treated with crushing of the "lost" stent into the external iliac artery wall. Meisel et al. published the first two cases of a similar complication during PCI followed by successful vascular stent implantation [4]. In the report of these authors the slipped stent was intentionally brought to the iliac artery and crushed into the wall of the unaffected vessel by another stent. In our case the stent was located in the site of a significant stenosis of the peripheral artery, but without complete blocking of the blood flow through the vessel. This probably prevented embolization to the distal parts of the artery with the onset of ischaemia of the lower limb and enabled treating that complication.
The excellent cooperation between the intervention cardiologist, vascular surgeon and radiologist should be emphasized.

\section{References}

1. Brilakis ES, Best PJ, Elesber AA, et al. Incidence, retrieval methods, and outcomes of stent loss during percutaneous coronary intervention: a large single-center experience. Catheter Cardiovasc Interv 2005; 66: 333-340.

2. Eggebrecht $\mathrm{H}$, Haude $\mathrm{M}$, von Birgelen $\mathrm{C}$, et al. Nonsurgical retrieval of embolized coronary stents. Catheter Cardiovasc Interv 2000; 51: $432-440$.

3. Bolte J, Neumann U, Pfafferott C, et al. Incidence, management, and outcome of stent loss during intracoronary stenting. Am J Cardiol 2001; 88: 565-567.

4. Meisel SR, DiLeo J, Rajakaruna M, et al. A technique to retrieve stents dislodged in the coronary artery followed by fixation in the iliac artery by means of balloon angioplasty and peripheral stent deployment. Catheter Cardiovasc Interv 2000; 49: 77-81. 